\title{
O QUE TRANSMITO DO QUE ME DISSERAM: NARRATIVIDADE EM AMBIENTE TRANSMIDIÁTICO
}

\author{
What spread than me Said: Narration in transmedia environment
}

Lo que me dijo propagación: La narración en el entorno transmedia

\author{
Marcelo Bolshaw Gomes \\ Professor do Programa de Pós- \\ Graduação em Estudos da Mídia \\ (PPGEM/UFRN) \\ marcelobolshaw@ufrnet.br
}

\section{Resumo}

A prática social de contar estórias - sejam desenhadas em quadrinhos, escritas em livros ou narradas oralmente - sempre foi objeto de reflexão e uma fonte importante de conhecimento. O presente texto apresenta os diferentes momentos dos Estudos Narrativos (clássico, estruturalista, mitológico e hermenêutico), destacando alguns de seus conceitos e metodologias. O objetivo é contrastá-los com as atuais narrativas transmidiáticas - aquelas que, segundo Jenkins (2008), se desenvolvem de forma desigual e combinada em várias mídias simultaneamente, formando um universo narrativo ou uma realidade analógica, em que a audiência passa a participar. E o resultado dessa reflexão é que até a teoria está se tornando meta narrativa interativa.

Palavras-chave: Estudos da mídia. Estudos narrativos. Narrativas transmidiáticas.

\begin{abstract}
The social practice of storytelling - be drawn comic, written in books or narrated orally - has always been an object of reflection and an important source of knowledge. This paper presents the different moments of the Narrative Studies (classical, structuralist, mythological and hermeneutical), highlighting some of its concepts and methodologies. The goal is to contrast them with current transmedia narratives - those who, according to Jenkins (2008), develop unevenly and combined in various media simultaneously, forming a narrative universe or an analog reality, where the audience begins to participate. And the result of this reflection is that even the theory is becoming interactive narrative goal.
\end{abstract}

Keywords: Media Studies. Narrative studies. Narratives transmedia.

\section{Resumen}

La práctica social de la narración - se elaborará cómic, escrito en los libros o narrado por vía oral - siempre ha sido un objeto de reflexión y una importante fuente de conocimiento. Este artículo presenta los diferentes momentos de los Estudios de Narrativa (clásica, estructuralista, mitológicos y hermenéuticas), destacando algunos de sus conceptos y metodologías. El objetivo es contrastar con las narrativas transmedia actuales - los que, según 
Jenkins (2008), el desarrollo desigual y combinado en diversos medios simultáneamente, formando un universo narrativo o un análogo de la realidad, donde el público comienza a participar. Y el resultado de esta reflexión es que incluso la teoría se está convirtiendo en meta narrativa interactiva.

Palabras clave: Estudios de Medios. Los estudios narrativas. Narrativas transmedia.

\section{INTRODUÇÃO}

Os estudos narrativos, como campo de reflexão teórica, têm duas origens opostas e complementares. Em primeiro lugar, estão os estudos clássicos a partir de A Poética de Aristóteles (2006). Em seguida, estão os diferentes tipos de estudos estruturalistas e de análise discursiva sobre várias formas de narrativa: Vladimir Propp (1978), Roland Barthes (2008), Gérard Genette (1972) e A.J. Greimas (1976, 1989). Em um terceiro momento, estão os estudos narrativos inspirados na psicologia junguiana, principalmente Joseph Campbell (1990) e Mircea Eliade (1992).

Com Umberto Eco (1976) e Paul Ricoeur (1994, 1995, 1997), os estudos narrativos passaram a também incluir os textos não ficcionais (como a crônica histórica e o jornalismo). Nessa quarta modalidade dos estudos, a formação cognitiva de nossa identidade enquanto sujeitos sociais é o resultado histórico das estórias que nos contaram e que contamos aos outros: a fabulação. O essencial então é saber como retransmitimos o que nos contaram.

E, nos dias de hoje, a grande maioria das estórias que nos contaram e que nós contamos são midiatizadas, isto é, são transmitidas, distribuídas e recebidas através dos meios de comunicação eletrônicos. Há aqui dois objetivos conexos: revisar as metodologias e conceitos dos estudos voltados para investigação das narrativas orais e das estórias escritas; e observar como e em que as narrativas audiovisuais se diferenciam se suas antecessoras, apontando uma metodologia de análise capaz de entendê-las e explicá-las.

\section{DESENVOLVIMENTO}

\section{1 - As 'escolas' narrativas}

As anotações que Aristóteles fazia para dar suas aulas de poesia e teatro, na Grécia entre os anos 335 e 323 antes Cristo, foram compiladas sob o nome A Poética, é o mais antigo livro conhecido sobre arte, dramaturgia e literatura. E seus conceitos são utilizados ainda hoje nos Estudos Narrativos. 
PROGRAMA DE PÓS-GRADUAÇÃO EM COMUNICAÇÃO DA UNIVERSIDADE FEDERAL DE SANTA MARIA

Quadro 1 - Conceitos clássicos ainda utilizados em estudos narrativos

\begin{tabular}{|l|l|}
\hline \multicolumn{1}{|c|}{ Conceitos } & \multicolumn{1}{c|}{ Definição } \\
\hline Catarse & $\begin{array}{l}\text { Purgação e esclarecimento, sofrimento sentido por nos projetarmos em situações dolorosas } \\
\text { simuladas, que nos causam alívio e bem estar. }\end{array}$ \\
\hline Mimese & $\begin{array}{l}\text { É a imitação criativa ou representação interpretativa da ação, através do qual aprendemos } \\
\text { atitudes, comportamentos e nos comunicamos. }\end{array}$ \\
\hline Intriga & $\begin{array}{l}\text { É o agenciamento de fatos, sujeitos e cenários - elementos estruturantes da narrativa - segundo o } \\
\text { desfecho desejado. }\end{array}$ \\
\hline
\end{tabular}

Fonte: Adaptado pelo autor de Ricoeur $(1994 ; 1995 ; 1997)$

Para os gregos, a noção de 'Diegese' era equivalente à de Intriga e oposto à de 'Mimese'. Diegese era entendido como "contar", o narrador descrevendo a ação e o que está na mente dos personagens; enquanto a Mimese era entendida como "mostrar" o que está acontecendo com as personagens através de seus pensamentos e suas ações. "Explicar o que é visto e mostrar o que é explicado.” Tanto Platão quanto Aristóteles, a arte era a Mimese (representação) da natureza. No entanto, para Platão, o mundo sensível era uma imitação do mundo inteligível. Já Aristóteles entendia a arte como representação significativa da realidade.

Os primeiros estudos narrativos estruturalistas se aproximam bastante da análise discursiva e da semiótica, trabalhando com a construção de uma gramática narrativa formada por paradigmas, estruturas e repetições universais entre as diferentes estórias analisadas, secundarizando os diferentes contextos culturais em que foram produzidas. $\mathrm{O}$ resultado dessa predominância levou a criação de fórmulas muito rígidas.

Quadro 2 - Contribuições estruturalistas aos estudos narrativos

\begin{tabular}{|l|l|}
\hline Autor & \multicolumn{1}{|c|}{ Contribuição } \\
\hline Propp & $\begin{array}{l}\text { Identificou 7 tipos de personagens, 6 estágios de evolução da narrativa e 31 funções narrativas das } \\
\text { situações dramáticas. }\end{array}$ \\
\hline Todorov & $\begin{array}{l}\text { Os personagens são mais importantes que as funções narrativas e o papel do narrador (mediador } \\
\text { entre autor e leitor) }\end{array}$ \\
\hline Greimas & $\begin{array}{l}\text { Não há apenas uma estrutura narrativa, mas várias estruturas sobrepostas. As estruturas profundas } \\
\text { seriam lógicas e acrônicas, formada por relações de contradição, oposição e contraponto (o quadrado } \\
\text { semiótico), aos elementos dessas relações, Greimas chamava 'actante' (que é equivalente a } \\
\text { personagem/função). Essas relações inconscientes entre os actantes das estruturas profundas se } \\
\text { tornam dinâmicas nas estruturas intermediárias e voltam a ser simultâneas nas estruturas } \\
\text { superficiais. }\end{array}$ \\
\hline
\end{tabular}

Fonte: Adaptado pelo autor de Propp (1978), Barthes, 2008, e Greimas (1976). 
PROGRAMA DE PÓS-GRADUAÇÃO EM COMUNICAÇÃO DA UNIVERSIDADE FEDERAL DE SANTA MARIA

Para esses autores, as estruturas narrativas englobam as estruturas linguística e semióticas de uma cultura. Usamos signos e discursos para contar estórias. As estruturas narrativas são o universo cultural (ou o campo específico em que os sujeitos se encontram antes de contarem suas estórias). E assim: 'Narrativa' é uma representação abstrata de uma série de acontecimentos conexos, envolvendo pessoas, ideias e lugares.

$\mathrm{Na}$ verdade, considera a semiótica narrativa um grande avanço em relação, tanto porque procura explicar as narrativas concretas e suas configurações temporárias por estruturas profundas atemporais (o que enriquece a noção de Intriga), como também porque, em relação ao próprio movimento estruturalista, a noção de narrativa como um processo que configura os textos, discursos e signos, retirando a análise linguística de um universo atomista sem intencionalidade.

O mais importante dos modelos narrativos do estruturalismo foi o elaborado por Greimas. Nele, as estruturas profundas correspondem ao inconsciente atemporal e é formado por três séries elementos, duplas de 'actantes' que formam 'funções' da narrativa: as relações de desejo ou de contradição (protagonista $\mathrm{x}$ antagonista e ajudante $\mathrm{x}$ sociedade); as relações de comunicação ou de contrariedade (protagonista \& ajudante e antagonista \& sociedade); as relações de ação ou de complementaridade (protagonista + sociedade e antagonista + ajudante). Esses elementos expressam relações arquetípicas que emergem à consciência através das estruturas discursivas da narrativa, seja na literatura de ficção, na história ou biografia.

A terceira geração dos estudos narrativos descende de Joseph Campbell, o conhecido mitólogo que levou as ideias de Jung aos campos da arqueologia, antropologia e história das religiões, que elaborou um modelo universal segundo o qual todos os grandes mitos fundadores das culturas humanas seriam, em última análise, uma narrativa universal: o 'monomito' (adaptado de James Joyce).

Campbell e seus seguidores partem do geral (do 'inconsciente coletivo', dos 'arquétipos') ao particular (o mito cultural específico), são universalistas e cultuam o sagrado como uma epifania transcultural. Enquanto as abordagens estruturalistas, no sentido contrário, observam o aspecto local do mito e da narrativa dentro de um quadro de referências globais. Ambos abordam 'o todo e as partes' - mas de modo bem diferente e até complementar em alguns aspectos. Os estruturalistas são mais dedutivos; os mitólogos, mais indutivos.

E o mais importante: o monomito de Campbell, delimitou os passos possíveis do herói arquetípico, em um "ciclo de iniciação" em sua trajetória do anonimato à consagração. 
O trabalho de Campbell influenciou cineastas como George Lucas (Star Wars foi concebido a partir da jornada do herói) e escritores como Christopher Vogler, roteirista de Hollywood e executivo da indústria cinematográfica que usou as teorias de Campbell para criar um memorando para os estúdios Disney, depois desenvolvido como o livro (1997).

Paul Ricoeur absorveu os conceitos de Aristóteles, do estruturalismo e da mitologia, utilizando a metodologia narrativa das estórias para demonstrar que a historiografia (a narrativa produzida pelos historiadores) é uma apenas construção poética.

Narrar história é enredar pessoas, instituições e ideias, é também enredar-se como narrador - seja em textos científicos ou jornalísticos. Assim, por um lado, a intriga é a inteligência narrativa e resulta da competência do escritor em agenciar incidentes de forma seletiva e significa, associando acontecimentos segundo seus valores, elegendo sujeitos como heróis e vítimas, encadeando sub-enredos em uma sequência lógica. E, por outro lado, a intriga deriva da 'fabulação' de seus leitores e do ambiente cultural em que ela é urdida.

Para Ricoeur, Mimese é a imitação criativa ou representação interpretativa da ação, através do qual aprendemos atitudes, comportamentos e nos comunicamos; e Diegese ou Intriga é o agenciamento de ações, sujeitos e cenários - elementos estruturantes da narrativa segundo o desfecho desejado. A Mimese é a imitação criadora da experiência viva. Ela não é uma cópia, réplica do idêntico; a Mimese produz sentido através da intriga, do agenciamento dos fatos (1994: 60). Ricoeur estabelece (1994: 85-132) três mimeses: a atividade cognitiva do enunciador; a configuração da linguagem; e a atividade cognitiva do leitor. E a Diegese é a Intriga narrativa, essa tríplice estrutura de configuração da linguagem.

De uma forma geral considera-se Diegese como sendo o conjunto de acontecimentos narrados numa determinada dimensão espaço-temporal, aproximando-a da noção de trama histórica ou intriga narrativa. Nessa versão, a Diegese não se confunde com o discurso do narrador nem com a narração propriamente dita, ela é um "ato da fala" que produz o narrado. Por analogia, ela também pode ser utilizada para designar o universo narrativo, em oposição à realidade externa de quem lê ('o mundo real' ou 'a vida real'). E por extensão, 'o tempo diegético' e o 'espaço diegético' são, assim, o tempo e o espaço que existem dentro da trama.

A tese central da trilogia Tempo e Narrativa (RICOEUR: 1994; 1995; 1997) é afirmar a identidade estrutural entre historiografia científica e narrativa ficcional.

\section{2 - Intriga e Catarse}

Um dos grandes feitos de Ricoeur nesse percurso, foi ressaltar a significativa reinterpretação das noções aristotélicas de intriga (como elaboração secundária) e catarse (como 
sublimação) que pode ser encontrada no clássico A Interpretação dos Sonhos (1990) de Sigmund Freud.

Para Freud, todo sonho seria 'a realização simbólica de um desejo inibido', mas nem sempre a expressão deste desejo é clara e inequívoca, ao contrário, haveria mecanismos psicológicos responsáveis pelo mascaramento simbólico dos impulsos recalcados. Freud chamaria esses mecanismos: condensação, deslocamento, processo de elaboração secundária, simbolismo e dramatização.

Lacan, ao tomar o inconsciente estruturado como uma linguagem e o sonho como um discurso a ser decifrado, reconheceu os mecanismos freudianos de condensação e de deslocamento nos termos 'metonímia' e 'metáfora', importados da linguística estruturalista. A dramatização e a simbolização são mecanismos coletivos análogos aos processos de condensação e deslocamento individuais.

A elaboração secundária é o processo pelo qual, à medida que se aproxima a vigília, o simbólico é reorganizada. Nos lembramos dos sonhos sempre de trás para frente, apagando seus detalhes e paradoxos. A Intriga narrativa também é regressiva, organiza a estória detrás para frente, buscando agenciar os incidentes em função do final desejado. Uma narrativa é sempre estruturada de trás para frente, planejando as reações dos leitores e dos personagens.

Segundo Freud, o processo de simbolização se explica através de quatro movimentos de defesa do ego: identificação, projeção, introjeção e sublimação. E, em trabalhos vários posteriores, Freud equiparou a noção de sublimação a uma 'catarse estética' - semelhante à catarse terapêutica.

Aristoteles fazia uma oposição entre a catarse trágica e o sentimento cômico. A tragédia expressa o conflito entre o passado mítico dos deuses e o presente da cidade; a comédia trata de ridicularizar os costumes e as figuras públicas, usando a ironia e o espírito cômico. Elas evocam sentimentos diferentes - uma é alegre; a outra, triste. Porém, o que caracteriza realmente a tragédia não é o final infeliz, mas o fato de: no trágico, a expressão do ser leva a transcendência da representação; no cômico, a representação da representação forma uma imitação crítica da realidade. São os dois extremos da linguagem: a transcendência catártica (o sublime) e a mimesis cômica (o gracioso).

Freud também considera o cômico ('o chiste') como sendo oposto ao trágico. Como o inconsciente funciona dentro da oposição dos princípios do prazer e da realidade, o trágico nos evoca a presença da morte e o cômico provoca uma carga pulsional psicofísica semelhante ao orgasmo, mais em menor intensidade. 
Em ambos os casos, no entanto, o protagonista é uma espécie de bode expiatório. Ele é 'um de nós, sofrendo por todos' e permitindo que o público transcenda a situação encenada através da sublimação, vivendo uma existência ampliada ao mítico e ao divino. Ou ainda, no caso da comédia, quando a depreciação satírica do Outro nos permite tomar consciência crítica de forma engraçada.

Jung foi o primeiro crítico da noção de simbolismo como recalcamento instintivo de Freud. Para ele, os símbolos são imagens universais (e não desejos reprimidos) e a sublimação é uma função psíquica compensatória entre quatro arquétipos principais do Inconsciente Coletivo. E esse quadrilátero psíquico também pode ser utilizado como uma estrutura narrativa de quatro personagens principais, com que tecemos nossa história:

Quadro 3 - Elementos principais do inconsciente narrativo

\begin{tabular}{|c|c|}
\hline Protagonista (EGO) & Narrador (SELF) \\
\hline Antagonista (SOMBRA) & Sagrado Feminino (ANIMA) \\
\hline
\end{tabular}

Fonte: Adaptado pelo autor de Campbell (1995).

E uma vez que os arquétipos psicológicos são universais, as histórias que contamos também são. Campbell e seus seguidores exploram este modelo.

\section{3 - Histórias Sagradas}

Há três comportamentos possíveis em relação às histórias sagradas: existem os que têm nostalgia das estórias tradicionais; os que pensam as estórias como modelos cognitivos para biografias; e os que entendem as narrativas sagradas e profanas como partes de um jogo complexo de identidade.

Tradicionalista, Sam Keen (SIMPKINSON, 2002, 43), por exemplo, crê que a multiplicidade de narrativas globais gera uma cultura descontínua e fragmentada, com rupturas de espaço/tempo e seu identidade narrativa local, que afasta os homens de si mesmos e da natureza.

Bateson (SIMPKINSON, 2002, 47) também considera a cultura atual descontínua, mas crê que há uma continuidade espiritual perpassando nossa história. O importante é viver a vida como processo criativo. Ser o autor de nossa história de vida, ser o artista e a própria obra de arte em evolução. As estórias, neste contexto, são encontros entre pessoas e imagens, uma forma de arte e terapia. 
Digamos nosso ponto de vista então sem arrodeio: é a distinção entre estórias de ficção e história 'real' que dessacralizou as narrativas ${ }^{1}$. A história e a ciência nos dizem quem somos e as estórias ficcionais nos dizem como não somos, ampliando assim nosso universo cultural. A narrativa ficcional expressa o 'não-ser'; é uma ampliação de nosso Self para compreender o outro, para expansão de nossas referências culturais. E a narrativa sagrada é um encontro do Ser com 'o que não é'.

Para o filósofo inglês R. G. Collingwood, há duas artes: a grande arte (art proper, a arte propriamente dita), é aquela capaz de levar a uma maior compreensão dos sentimentos e a uma ampliação e regeneração da consciência; e a má arte, a arte 'assim chamada' (so called)", que serve a corrupção da consciência e têm dois tipos ideais: o divertimento e a 'arte mágica' ou utilitária (COSTA, 2006, 30).

Com base nesses critérios, pode-se até dividir as narrativas entre sagradas e profanas. No entanto, nos tempos da globalização, com as estórias industrializadas através da mídia, essa distinção não funciona. Na prática, há sempre os três elementos - a ampliação e reafirmação da identidade cultural e ética (o aspecto cognitivo); a diversão e o entretenimento (o aspecto lúdico); e a sugestão política de mudança e/ou de conservação dos valores sociais (o aspecto pedagógico) - distribuídos em diferentes graus, tanto no caso das narrativas ficcionais como das narrativas ditas 'reais', as jornalísticas ou cientificas.

Walter Benjamim em A Obra de Arte na era de sua reprodutividade técnica (1983, 528) ressalta o impacto que a produção em série de objetos pela indústria teve sobre a percepção. Houve um tempo em que apenas as moedas e a xilogravura eram objetos produzidos em série. A obra de arte era única no tempo e no espaço e isso lhe conferia uma áurea, uma presença sagrada. Hoje praticamente tudo é reproduzido de modo idêntico. A arte, então, deixou de ser sagrada, 'objeto de culto' para se tornar expressiva dos sentimentos e crítica da injustiça social.

Benjamim (1985b) observa que, com a reprodutividade técnica, também há uma mudança na forma como contamos estórias.

No ambiente tradicional, as estórias eram transmitidas oralmente e, portanto, eram repetidas sempre da mesma forma - como exigem as crianças em seus primeiros anos. Quando ganhavam versões escritas, os narradores não se assumiam como autores da narrativa:

1Trabalho essa questão em A estória de Jesus Cristo como narrativa (GOMES, 2011) - uma estória é sagrada porque é histórica e mítica ao mesmo tempo, assim como a vida de Sidarta Gautama, a dos orixás africanos e de outros personagens históricos (ancestrais de uma comunidade) que se tornaram, pela sua história de vida, entidades simbólicas (deuses ou forças da natureza). 
Homero, Hesíodo, Virgílio, Apuleio apenas recontam narrativas que ouviram. A ênfase cognitiva era na narrativa.

No ambiente moderno, no entanto, o contador de estórias (escritores, cineastas, artistas) deve 'ser criativo', original e primar pela novidade, não só contando uma mesma estória de diferentes formas, mas sempre contando novas estórias. Tornou-se lugar comum não apenas recontar histórias clássicas com um estilo autoral, mas também combinar histórias de diferentes culturas e épocas, relacionando-as, misturando seus personagens e textos, fazendo citações para serem reconhecidas. A ênfase moderna é no narrador.

Em outros textos (1983, 29-56), Benjamim diz que artista moderno é que tem a 'áurea', que é sua vida que dá sentido à sua obra. Para ele, a produção em série deslocou a singularidade da arte do campo do objeto para o interior do sujeito, transformando a 'espiritualidade da criação' na 'genialidade do criador'. Tal fato instaurou a metalinguagem (ou a relação explícita entre o enunciador e a referência) no coração da arte moderna e das narrativas audiovisuais. No contexto narrativo moderno, o narrador é um sub personagem e os personagens, sub narradores das estórias.

E se a ênfase clássica é na forma narrativa e a ênfase moderna é centrada no narrador e na metalinguagem, a ênfase atual está narratividade do receptor, a fabulação. O público deixa de ser contemplativo e passa a interferir na construção da narrativa, orientando o narrador e os personagens.

Porém, o fato da sacralidade narrativa hoje é do receptor que se torna co enunciador das estórias que lhes contam ainda é insuficiente para entender o valor das histórias sagradas. Na verdade, a "jornada do herói” é um processo simbólico de formação histórica e mítica do sujeito no ocidente, nas sociedades patriarcais. Outras culturas tem histórias sagradas que fogem bastante aos modelos narrativos.

Será que, ao invés de compreender e explicar o efeito espiritual das narrativas sobre nossas vidas, os estudos narrativos apenas padronizaram ainda mais as estórias, gerando modelos para a produção em série de enlatados audiovisuais pela grande indústria cultural?

\section{4 - Narrativas transmidiáticas}

Através das narrativas de ficção é que melhor podemos compreender o efeito de sentido indireto do narrado sobre o vivido (ou sobre o vivo). Toda narrativa imaginária ensina a finitude do tempo. E cada narrativa nos conta 'como viver', narrando sobre uma forma de vida aparentemente diferente, mas essencialmente similar à nossa. Samuel Taylor Coleridge criou a noção de "suspensão voluntária da descrença". Para ele, narrativas fantásticas ou não 
realistas ressaltam outros aspectos da realidade. Por exemplo, para enfatizar o ambiente olfativo, criamos um universo em que apenas o herói tem nariz.

Hoje, no que diz respeito à televisão e às narrativas seriadas atuais, a Diegese agora é mais bem compreendida como um 'universo narrativo'. O universo narrativo é uma segunda realidade (BYSTRINA, 1995), um 'mundo paralelo' à realidade cotidiana do público, que funciona uma analogia de comportamento, 'um espelho' em que alguns aspectos culturais semelhantes são ampliados e outros são desconsiderados ou modificados. Um universo narrativo é formado por várias estórias dentro de uma narrativa maior subdividida em partes. As estórias atuais são 'seriadas', isto é, divididas em episódios regulares que usam ganchos de tensão e suspense para manter a atenção da audiência durante períodos segmentados de tempo de recepção: o romance de folhetim; as histórias em quadrinhos; as radionovelas, em que a narrativa seriada se fragmentou ainda mais devido as inserções comerciais. A partir dos anos 60, chega-se a grade de programação da TV e a narrativa seriada audiovisual em sua forma atual.

$\mathrm{Na}$ narrativa seriada, o contexto de recepção estruturado como 'cotidiano', isto é, como a fabricação de dias aparentemente iguais pela indústria cultural. As narrativas seriadas reforçam e são geradas pelas rotinas de vida da cultura mecanizada da sociedade industrial. Eis porque os seriados são frequentemente chamados de 'enlatados'. O consumo fragmentado e descontinuo das narrativas seriadas levam a uma recepção repetitiva, cumulativa e aberta, onde o público interfere na narrativa enquanto ela se desenvolve ${ }^{2}$. Aos poucos as narrativas audiovisuais seriadas foram se tornando mais interativas, sendo adaptadas para vários suportes e se transformaram nas atuais narrativas transmidiáticas. Assim, além do universo narrativo e da participação do receptor, há outro fator importante nas narrativas atuais: elas se distribuem de forma desigual e combinada em diferentes suportes ao mesmo tempo.

\footnotetext{
${ }^{2}$ Omar Calabrese (1987) formulou um modelo para análise de narrativas seriadas em três estruturas. A primeira estrutura é o contexto de enunciação coletivo e não autoral. Vários profissionais participam da produção em série em regime colaborativo. Hoje, no entanto, há uma profunda desindustrialização da produção audiovisual e a tecnologia permite fenômenos autorais como o animê e o mangá japoneses, feitos de forma artesanal. É claro que a grande mídia ainda ocupa o lugar de grande contadora de estórias da vida contemporânea, mas o computador permite a possibilidade da produção de estórias audiovisuais em série por um único autor. Já a segunda, representa a adequação das mensagens (e do pensamento) a este modelo serial. A serialidade narrativa proporciona linguagem fragmentada e descontínua, na qual a repetição de alguns elementos e a variação de outros, bem como a imposição de um determinado ritmo de exibição determina características próprias e específicas. Os elementos variáveis funcionam de forma cumulativa, estabelecendo uma continuidade com as expectativas e conhecimentos do público, formando gradativamente um universo narrativo de analogia com a narrativa da vida real. E a terceira função corresponde à recepção, ao consumo descontinuo e fragmentado das narrativas. Além do público não ser presencial, ele também não é passivo, interferindo diretamente na narrativa enquanto ela se desenvolve.
} 
O termo 'narrativa transmidiática' foi elaborado por Jenkins (2008), levando em conta esses três elementos: a participação da audiência na narrativa; a sugestão de que o universo narrativo é uma realidade; a presença dos principais personagens da narrativa em diferentes suportes. Os três elementos são interdependentes: a participação do público se deve ao seu envolvimento emocional com a realidade narrativa; ampliada pelas narrativas em vários suportes, muitas delas produzidas pelos próprios fãs ${ }^{3}$. Assim, não se trata apenas da narrativa literária adaptada em outros suportes ou de enfatizar seus personagens (como na TV), mas sim de criar e gerir um universo de várias estórias em que diversos personagens interagem segundo as regras próprias do universo, através de livros, filmes, quadrinhos, programas de $\mathrm{TV}$, sites de internet, games, etc.

A passagem das narrativas terciárias seriadas da TV e do rádio para as atuais narrativas transmidiáticas (ou da Mimese audiovisual simples para Mimese emocional e da Diegese-intriga para Diegese-universo) se deu de forma gradativa e cumulativa, sem grandes rupturas, em grande parte, através da autoconfiguração das próprias narrativas.

$\mathrm{Na}$ narrativa seriada, sempre houve retorno da recepção: as telenovelas fazem pesquisas de opinião, o rádio usava o telefone e até os romances de folhetim recebiam cartas. Recentemente, no entanto, a recepção de produtos midiáticos está deixando de ser individual (e individualizante) e se tornando em uma atividade de consumo grupal.

Atualmente, há diferentes pontos de vista sobre o tema. Há os que acreditam que recepção do cinema e da TV (assistida em ambiente familiar nos tempos da válvula) já era coletiva e que a recepção individual é própria da leitura silenciosa - Walter Benjamin, por exemplo. Outros, como Jenkins, pensam que apenas agora com a cultura participativa e com segmentação interativa das redes sociais é que estamos elaborando uma recepção grupal do conteúdo midiático. Podem-se somar esses pontos de vista: a recepção era coletiva, mas circunstancial, e só agora está se perenizando em grupos.

\footnotetext{
${ }^{3}$ Segundo Jenkins, desde meados dos anos 90 já é possível identificar produções de narrativas transmidiáticas na indústria de entretenimento norte-americana. Geralmente, a história é introduzida por uma mídia (um filme, por exemplo) e incrementada através de outras (séries de TV, sites com diversas funções, blogs, games, quadrinhos, animações, romances), ampliando seu desenvolvimento narrativo e expandindo seu universo, permitindo não apenas a criação de novos conflitos, novas estórias e personagens, como também novas maneiras de se consumir e interagir com esse universo com a participação interativa do público através de blogs, sites, etc. Exemplos? Dawson's Creek (um seriado teem agregado a um site onde é possível acessar o computador do personagem principal a partir de seu computador: o Dawson's Desktop), A bruxa de Blair (vídeo imitando uma gravação caseira associada a documentários falsos de modo a construir um universo ficcional aparentemente verdadeiro); e Lost, que utilizou vários recursos: minivídeos para celular com estórias rápidas que não passam na TV, perfis dos personagens na internet, podcasts (arquivos de áudio) semanais discutindo os episódios e entrevistando os atores, diretores, produtores e roteiristas da série, a lostpédia (uma enciclopédia wiki criada por fãs), e um site falso da empresa aérea Oceanic Airlines, supostamente responsável pelo desaparecimento dos personagens após um acidente.
} 
PROGRAMA DE PÓS-GRADUAÇÃO EM COMUNICAÇÃO DA UNIVERSIDADE FEDERAL DE SANTA MARIA

A Diegese, por sua vez, se complexificou ainda mais em virtude da elaboração de universos narrativos, passando a ter várias perspectivas de interpretação, de autores, de público e dos próprios personagens das narrativas. A partir dos anos 90, a transmediação passou a se desenvolver, primeiro na indústria do entretenimento e depois através da publicidade e da propaganda política, não apenas mandando mensagens combinadas em diferentes suportes, mas sobretudo desenvolvendo universos narrativos com estratégias de incentivo à participação do público, fidelizando consumidores às marcas e fazendo-os coprodutores; ou tornando simples eleitores em militantes sazonais de campanhas específicas.

E a Mimese evoluiu lentamente da mera representação audiovisual do corpo descontextualizado pela televisão para a Mimese interativa, poética, musical e cromática de sensibilização afetiva difundida nas redes digitais.

No entanto, além do universo narrativo e da participação do receptor, há outro fator importante: o tempo.

\section{5 - Tempo e narrativa audiovisual}

Além da universo narrativo e da participação do receptor, há um outro fator importante: o tempo. A distinção entre o tempo levado para contar e o tempo das coisas contadas, permite a Ricoeur estudar três textos literários reflexivos sobre a própria narrativa (1995, 183-274), três 'fábulas do tempo e sobre o tempo' em sua relação com a linguagem: Mrs. Dalloway, de Virginia Woolf (183-199); A montanha mágica, de Thomas Mann (199223); e Em busca do tempo perdido, de Marcel Proust (223-255).

Transpondo-se essa noção de dupla dimensão temporal da narrativa e da meta narrativa do universo literário das 'fábulas do tempo' de Ricoeur para o universo audiovisual, observa-se que o cinema de ficção científica é o principal laboratório de experiências temporais e está sempre associado às ideias de utopia e máquina.

Joseph Campbell (1990) considerava ficção científica como a mitologia de nossos dias, refletindo sempre temas subjetivos atuais em um ambiente tecnológico futurista. Para ele, 'a máquina' é o principal antagonista dessas narrativas neo mitológicas. A máquina é desumana, fria, impessoal. Pode ser bem utilizada, mas também pode nos escravizar.

Hoje, em nossa luta contra e a favor da máquina, se observa um crescimento exponencial das narrativas de paradoxo temporal, as estórias sobre viagens no tempo em que uma mudança em um evento no passado pode alterar o futuro da narrativa e o presente narrativo. Esse modelo está presente em filmes bastante diferentes entre si: De volta para o 
PROGRAMA DE PÓS-GRADUAÇÃO EM COMUNICAÇÃO DA UNIVERSIDADE FEDERAL DE SANTA MARIA

futuro; O Exterminador do futuro; O Som do Trovão; Efeito Borboleta; além de inúmeros seriados e narrativas de outros gêneros.

A trilogia Matrix também trabalha com a ideia de paradoxo temporal, mas dá ênfase à meta narrativa dimensional. Há duas realidades paralelas, na primeira, ilusória, vivemos nossas vidas normalmente; mas na segunda somos dominados por máquinas, que vivem de nossa energia através de um regime de dependência química e hipnose audiovisual. Assim, a relação entre a realidade externa e o universo narrativo é duplicada (e invertida) dentro da narrativa, com a realidade sendo colocada como uma ilusão holográfica e o universo narrativo (por trás do espelho, dentro do computador) sendo posto como a realidade verdadeira.

$\mathrm{Na}$ estória, essa dupla realidade invertida é resultado de simbiose entre os homens e as máquinas. Neo, protagonista e narrador, é o messias virtual que tem por missão derrotar a Matrix e o grande Programador, que controla e planeja tudo, inclusive rebeliões periódicas para otimização do sistema. Jenkins considera a franquia Matrix (que além dos filmes, inclui desenhos animados, histórias em quadrinhos, games dentro do mesmo universo ficcional) um marco em termos de transmediação, principalmente na participação do público dentro do universo narrativo proposto.

Por outro lado, o alargamento deste universo por novas estórias também acarretou em uma perda no efeito de sentido de dupla realidade invertida da ideia original de Matrix. Nos desenhos animados da franquia, Animatrix, narra-se como as máquinas chegaram ao poder e escravizaram os homens, implodindo o jogo entre tempo narrativo e tempo real, pela qual seria possível sair da Matrix ilusória em que vivemos a qualquer momento. A narrativa se torna apenas uma ficção da realidade e não uma teoria da conspiração real.

Há ainda as narrativas de laço de recorrência temporal. Nessas narrativas, a ação que se repete da mesma forma menos para o protagonista em um 'laço no tempo' (ou time loop), uma situação em que o tempo corre normalmente durante um determinado período, mas em certo ponto o tempo 'salta para trás', de volta ao ponto inicial, como um disco de vinil riscado, repetindo o exato período em questão. A maioria dos jogos eletrônicos atuais foi elaborada como narrativa de laço de recorrência temporal.

O importante quando assistimos a essas narrativas é entender que eles representam o tipo de experiência de vida cotidiana e tem bastante ressonância emocional. Será que vivemos em uma sociedade semelhante à descrita no filme Matrix, aprisionados por tubos químicos e hipnotizados por sistemas audiovisuais, sonhamos viver outra vida enquanto somos dominados por máquinas? Vivemos a experiência subjetiva do laço temporal recorrente, em que os dias se repetem iguais? 


\subsection{Teoria das mídias}

Por 'mídia primária' entende-se toda comunicação presencial, em que os interlocutores partilham de um mesmo contexto, sediada no corpo, principalmente na fala (PROSS, 1997). Pierre Levy (1993) chama essa forma de comunicação de 'oralidade', a primeira tecnologia da inteligência, que segue um modo de interação um-um.

'Mídia secundária' aqui é entendida como a comunicação em que os contextos de transmissão e de recepção se dissociaram. Segundo Pross, essa é a mídia secundária, formada por suportes extra corporais em que a mensagem fica fixa no tempo e no espaço. A escrita do ponto de vista social e cognitivo é um fator determinante para o aparecimento da história, da memória social, do pensamento científico objetivo. Para Levy, é o modo de interação ummuitos, em que um emite e outros recebem passivamente.

E 'mídia terciária' ou elétrica implica na existência de suportes tecnológicos nos dois polos da comunicação através da linguagem audiovisual, que Levy entende por modo de interação muitos-muitos. Trata-se, na verdade, da convergência prática de todos os meios de produção, comunicação, circulação, enfim de toda sociedade global em torno de um modelo de organização em redes em um regime cultural de hipervisibilidade e de simultaneidade de tempo. Também Kerckhove (1987) utiliza os termos 'contexto', 'texto' e 'hipertexto' - no mesmo sentido. Há sempre um antes e um depois da escrita. O computador traz parcialmente de volta o arcaico, o mítico, o tempo simultâneo, o corpo, o grupal ...

Na mídia primária, a imagem bidimensional 'entra' no observador distraído, a partir de estímulos ao hemisfério direito cerebral. Com os sinais abstratos da mídia secundária, passase a trabalhar (com esforço e concentração) o lado esquerdo do cérebro. Desenvolve-se, então, o pensamento lógico, a perspectiva da história e da objetividade. E, agora, com a mídia terciária, trabalha-se com os dois hemisférios simultaneamente: o simbólico e o algoritmo.

Em outro texto (GOMES, 2012), definiu-se essa tripla estrutura das três mídias (primária, secundária e terciária) como uma máquina social de fabricação do tempo e ao conjunto das três funções cognitivas midiáticas - a memória do passado, a percepção do presente e a simulação do futuro - ao mito grego das moiras, as tecelãs do destino homens e dos deuses. As três Moiras representam a existência inflexível do tempo acima e além da 
morte e do destino - quase fora da narrativa. Essa é o principal antagonista do anti-herói pósmoderno (protagonista/narrador) em sua narrativa tragicômica ${ }^{4}$.

As moiras também representam as três dimensões de efeito que as narrativas têm sobre seus leitores/ouvintes. As narrativas têm uma dimensão emocional (causam alegria, medo, raiva, amor) que funciona a partir da noção de pertencimento territorial, da ampliação e/ou reafirmação da identidade étnica. Essa dimensão corresponde à bruxa do presente. Também há uma dimensão psicológica em que nossa mente associa e compara as estórias simbólicas à nossa história biográfica, representando a bruxa do passado. E as narrativas possuem ainda uma dimensão sagrada em que nosso espírito sonha seus destinos - é a bruxa do futuro. Além das emoções e das tradições, essa é a dimensão sagrada das narrativas que, através da imaginação individual, nos faz sonhar e reavaliar a vida. Para Bystrina, a arte é "uma mensagem que comunica a si mesma, que tem por referência principal sua própria estrutura". $(1995,24)$

\subsection{Mimese e Diegese transmidiáticos}

Bem vistas essas questões, pode-se agora combinar as noções das três mídias (e de sua união na transmídia) com as de Mimese e Diegese.

Quadro 4 - Mídias x Mimesis

\begin{tabular}{|l|l|l|l|}
\hline & MIMESE & DIEGESE & RECEPTOR \\
\hline Mídia primária & Memória do corpo & Ideia, arquétipos & Interlocutor \\
\hline Mídia secundária & Representações Mentais & Intriga Histórica & Leitor \\
\hline Mídia terciária & Luz e Som & Estrutura Narrativa & Telespectador \\
\hline Transmídia & Intenção, emoções, sentimentos & Universo narrativo, 2a realidade & Jogador \\
\hline
\end{tabular}

Fonte: Criado pelo autor de Campbell.

No paradigma presencial da mídia primária, a Mimese é a memória do corpo, a imitação de gestos, sons, palavras. E a Diegese é o conteúdo do que transmitido: lendas, preces, conceitos. Segue-se assim o modelo de Platão em que o corpo mimetiza o universo

\footnotetext{
${ }^{4}$ Dois exemplos concretos da presença das moiras como antagonistas do herói pós-moderno: a grafic novel Sandman, de Neil Gaiman (GOMES, 2013a); e o seriado de TV Xena, a princesa guerreira (GOMES, $2013 \mathrm{~b}$ ).
} 
arquetípico universal. A Mimese é corporal, espontânea e presencial. A Diegese é o conteúdo comunicado, a 'ideia'.

Na comunicação secundária, há uma inversão e os conceitos de Aristóteles são mais aplicáveis: a Mimese é uma representação mental foneticamente codificada da realidade; e a Diegese corresponde à duração e as intensidades do discurso no texto. Com o aparecimento da mídia secundária, surge também a Máquina Social de Pensamento. Agora, a Mimese é a memória social objetiva, descontextualizada e mimetizada através de representações mentais codificadas; e a Diegese, por sua vez, corresponde à noção de História.

A mídia secundária não anula a primária, mas se sobrepõe a ela. Assim, a Mimese e Diegese primárias continuam ativas nos contextos de recepção dos processos de Mimese e Diegese secundários.

E com o advento da mídia terciária e da Máquina Social da Imaginação, a Mimese tornou-se uma experiência do corpo recontextualizada por imagens e sons mediados por tecnologia; e a Diegese se tornou uma estrutura narrativa, a intriga. A diferença fundamental entre Diegese secundária e terciária, é que a intriga histórica não tem consciência de que é uma construção poética e se acredita científica, objetiva e absoluta; enquanto a intriga narrativa sabe aonde quer chegar e se percebe como sendo uma estrutura metalinguística.

No contexto da comunicação terciária, também há uma nova duplicação das polaridades. Mimetiza-se o corpo e a representação do mundo descontextualizada; e a Diegese produz uma intriga dupla: o sentido (o final, se feliz ou trágico) e a estrutura discursiva da narrativa. Nas narrativas seriadas, há ainda uma estética da repetição: as Mimesis tende a serem regulares e constantes; todos os dias nos mesmo horário, no caso do rádio e da televisão; ou a qualquer momento, em várias mídias, nas narrativas transmidiáticas. E a Diegese, nesse cenário convergente, agora corresponde à segunda realidade, aos universos narrativos paralelos que criamos para compreender nosso mundo. Nele, não mimetizamos apenas comportamentos, atitudes e conceitos, mas sobretudo emoções, sentimentos, intenções, subjetividade. As narrativas transmidiáticas enfatizam o aprendizado ético e emocional. Essa ênfase em trabalhar situações emocionais (medo, alegria, raiva, etc) se tornou mais evidente principalmente pela influência recente dos mangás e os animês japoneses.

Esse quarto momento midiático também não anula os anteriores. Temos agora quatro Mimeses (corporal, mental, audiovisual e emocional) e quatro Diegesis (arquetípica, histórica, meta narrativa e transdimensional), embutidas e combinadas na comunicação transmidiática contemporânea. Na mídia primária, a Mimese é presencial e espontânea, ancorada no corpo como suporte em um contexto único de interlocução; a Diegese é o conceito, a ideia, o 
significado. Na mídia secundária, a Mimese é signo, representação mental descontextualizada e codificada em marcas fonetizadas; e a Diegese é história, memória social e percepção objetiva do tempo. E, na comunicação terciária e transmidiática, a Mimese é uma rede de emoções transmitidas por frequências de luz e som serializadas no tempo-espaço; e a Diegese é um universo narrativo paralelo que se confunde com a realidade de vida do público, que passa a interagir com a narrativa que lhe é contada.

Esses quatro momentos narrativos correspondem aos espaços antropológicos de Pierre Levy: a Natureza, o Território, o Mercado e o Saber. Um exemplo dado por Michel Serres (LEVY, 2007, 15): nosso nome e sobrenome são nossas identidades no espaço da Terra; nosso endereço, nossa identidade no espaço territorial; a profissão, a posição que ocupamos no mundo das mercadorias; e, atualmente, estamos definindo uma quarta identidade para o espaço do saber: a senha, a impressão digital, o avatar, o DNA. E a definição desta quarta identidade contemporânea - se individual ou coletiva, se anônima ou genética, se consciente ou involuntária - ainda está em construção.

\section{CONSIDERAÇÕES}

Toda intriga é feita a partir de dois personagens (protagonista e antagonista) e de um narrador externo, aparentemente não envolvido, que os enreda em um conflito.

Um texto teórico não é exceção. Aqui, por exemplo, apresentamos as gerações de estudos narrativos de modo que o estruturalismo e a mitologia comparada ocupassem o lugar de predecessoras teóricas da hermêutica de Ricoeur. Depois estabelecemos um conflito central, apresentando a questão da mídia e da globalização das narrativas e a incapacidade dos estudos narrativos de darem conta de compreendê-las e explicá-las.

Ora, há duas grandes deficiências na hermenêutica de Ricoeur: a sua preferência pela escrita como campo de inovação semântico (isto é, do ainda não dito, do inédito) em detrimento do caráter cognitivo das imagens, presentes nas narrativas mitológicas; e o fato dele não perceber as mudanças cognitivas resultantes do regime de tempo simultâneo instaurado da comunicação instantânea.

Para resolver esse conflito, fizemos uma atualização das ideias de Ricoeur (1994, 1995, 1997) em relação ao novo regime de simultaneidade de tempo e hipervisibilidade instaurado pelas mídias terciárias. As mídias tornaram-se assim as antagonistas de nosso texto e Ricoeur, o protagonista invisível da nossa meta narrativa (um herói aparentemente impotente para atualidade). Convocamos, em seguida, vários ajudantes para fortalecer a 
hermenêutica filosófica e literária de Ricoeur, dando a ela novos instrumentos analíticos para o estudo das narrativas midiáticas atuais: Benjamim, Cabrese, Jenkins ... Graças a essas alianças que conseguiu-se equilibrar forças com o inimigo epistemológico - a máquina midiática; sendo então capaz de compreendê-la por inteiro e assim assimilá-la na narrativa hermenêutica.

As narrativas audiovisuais da mídia, principalmente a ficção científica, ocuparam o lugar do arquétipo feminino, que é raptada pelo antagonista, precisando ser resgatada pelo protagonista. Sugeriu-se ainda que, tanto o casamento entre 'os mocinhos' (a hermenêutica e a imaginação narrativa) como a vitória do vilão (a mídia), nos leva de volta às estórias sagradas, re-unindo as narrativas ficcionais e históricas que foram separadas desde tempos imemoriais.

Chega-se então ao clímax do suspense: A Intriga midiática é legítima? Qual a solução para o conflito triangular entre narrativa, tempo e meta comunicação? Como integrar o esboço de uma teoria interpretativa das mídias à hermenêutica em geral e à nossa meta narrativa em particular? E finalmente: como terminaremos este texto?

Uma boa classificação primária para narrativas (sejam fictícias ou reais) pode ser proposta a partir da solução do conflito, subdivindo-as em: as de final feliz e as de fim trágico (independente de elementos dramáticos cômicos ou trágicos). As históricas com final feliz são as pedagógicas e hipnóticas. São narrativas para produzir esperança e fazer com que todos acreditem que 'as coisas vão dar certo', fazendo com elas realmente deem certo. E as histórias com fins trágicos são aquelas que querem nos alertar que as coisas podem terminar mal. As narrativas trágicas são as que, pela catarse transcendente da representação, expiam nossas culpas e medos, nos ensinando a viver uma vida sem ilusões.

Bom, coerentes com tudo que foi dito e defendido até aqui, dois finais podem se constituir para este ensaio:

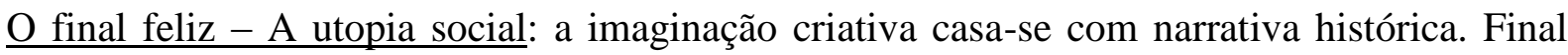
que aponta para uma nova configuração cultural em escala planetária em que a narrativa da história escrita se encerra com o desfecho previsto desde o começo: a nova jerusalém do Apocalipse é um retorno ao jardim do éden na Gênesis, como sustenta a exegese do crítico Frank Kermode (RICOEUR,1995, 40-47). E, nesse desfecho utópico - acrescente-se por minha conta: a mídia teria a missão histórica da condução narrativa deste 'happy end' escatológico, re-combinando conscientemente os aspectos simbólico e referencial da linguagem em narrativas integrais; reeducando a sociedade para uma vida menos destrutiva. O fim trágico - A distopia social: seremos controlados por máquinas. A intriga das mídias não é mais que mera manipulação de um poder gerenciado por quem não sabe o que realmente o 
quer e acaba se tornando um fantoche das próprias narrativas. É o universo do 'funcionário do aparelho' descrito por Flusser: o 'nomadismo sem corpo', em que a alma viaja através das imagens técnicas; o apocalispe da mídia devoradora da 'escala de abstração' que nanifica a linguagem (BAITELLO, 2010, 13-59).

Um jornalista experiente, ao escreve uma matéria, intriga suas fontes, colocando seus entrevistados na posição de protagonistas e antagonistas. Ele deve, no entanto, deixar claro sua posição de forma elegante e deixar a decisão final para seus leitores. Somente assim ele será ético e justo. Creio que o mesmo vale para textos científicos ou filosóficos. Há artimanhas narrativas que o jornalista pode ensinar ao pesquisador, como também há a disciplina e o rigor lógico que o escritor aprende com o cientista. E essa é a dupla intenção desse texto: por um lado, enriquecer os Estudos Narrativos com conceitos e noções das teorias das mídias; e, por outro, levantar elementos para estudar a narratividade dos discursos audiovisuais.

Porém, da presente meta narrativa, pode-se tirar algumas conclusões:

Em primeiro lugar, constatou-se que, em relação às narrativas audiovisuais, é preciso enfatizar mais os diferentes contextos sócio históricos de recepção midiática do que em relação às antigas narrativas orais e escritas (cuja a análise era centrada nos contextos sócio históricos de produção e na linguagem). E mais: que ao se tornar interativa, a narrativa audiovisual incita o receptor à co enunciação.

Para Ricoeur, 'Narrar' passa a ser considerado um 'ato da fala' intermediário entre 'Descrever' e 'Prescrever'. A mediação entre o relato (de uma ação) e seu modelo ideal (prescrição) resulta ou se estabelece por meio/na narrativa. Ricoeur associa o aspecto prescritivo da linguagem, à função poética e ao futuro; o aspecto narrativo, à função metalinguística e ao passado; e o aspecto descritivo à função referencial e ao presente. $\mathrm{Na}$ perspectiva contemporânea, o aspecto descritivo da linguagem corresponde à mídia primária e ao corpo; o aspecto narrativo, à mídia secundária e à memória; e o aspecto prescritivo, à mídia terciária e à simulação virtual do tempo, entendido como uma projeção do futuro, como o exercício da imaginação no horizonte dos possíveis.

Talvez por ter sido influenciado pelo estruturalismo que assimilou, Ricoeur considera a Mimese da linguagem, a autoconfiguração da narrativa, como a mais importante das três para a intriga. Mas, em se tratando de narrativas audiovisuais interativas, a Mimese do receptor (a catarse criativa) é de longe a mais significativa para construção da narrativa em tempo real. O jogador de games de imersão, por exemplo, é um novo tipo de receptor, simultaneamente interlocutor, leitor e telespectador. 
E mais: além dos jogos de imersão holográfica virtual permitirem um desempenho cognitivo mais complexo, eles também transformam os jogadores em coautores de uma narrativa hipertextual em constante e permanente reconstrução. É a Mimese do receptor que reconfigura toda intriga, as Mimesis da linguagem e dos enunciadores primários. Os jogos holográficos interativos The Sims Series e Second Life são exemplos de como vários usuários podem construir empresas, cidades, países, trabalhando na internet em regime colaborativo.

Então, através de uma hermenêutica centrada na recepção e não na linguagem, apresentou-se a teoria das três mídias de Pross e aplicaram-se as noções narrativas de Mimese e Diegese à comunicação primária, secundária, terciária e transmidiática. Constataram-se assim, na narrativa transmidiática, quatro Mimeses: corporal, mental, audiovisual e emocional; e quatro Diegesis: arquetípica, histórica, meta narrativa e transdimensional.

Elaboraram-se ainda os conceitos de Máquina Social de Pensamento e de Máquina Social da Imaginação. Resta dizer que a Máquina de Pensamento corresponde à Mimese do enunciador e a Máquina de Imaginação equivale à Mimese da linguagem. E que a construção de máquina cognitiva global, uma nova inteligência coletiva planetária descentralizada e sincronizada, formada pela utilização plena e consciente das máquinas sociais do pensamento e da imaginação, corresponde à Mimese do receptor.

Nós somos essa máquina.

A identidade narrativa da espécie humana, a história que contamos para nós mesmos com objetivo de definir quem somos, nos leva a crer que somos uma parte integrante da ‘Máquina biológica de aprendizado', que nossa função no universo em que habitamos não é somente a de aprender, mas também de gerenciar o aprendizado de outras espécies. E que estamos apenas retornando à consciência da inteligência coletiva que nos formou.

Preocupado com a desgraça dos homens bons e a boa graça dos maus, o filósofo Rene Descartes sonhou que o universo era um relógio e Deus, um relojoeiro. Desde então estamos aprisionados na ideia de um universo mecânico, que funciona independente das vontades. E mesmo que alguns, como Edgar Morin, Fritjof Capra e o próprio Harry Pross ${ }^{5}$, desejem ver o universo como uma rede sistêmica de seres vivos integrados ao meio ambiente, a noção de 'máquina' ainda permanece como um paradigma epistemológico intransponível (um vilão necessário) para compreensão de nós mesmos e do cosmo em que vivemos.

\footnotetext{
${ }^{5}$ A mídia antes da máquina - entrevista de Harry Pross a Norval Baitello Junior. Acervo do CISC: Centro Interdisciplinar de Semiótica da Cultura e da Mídia. Publicado no JB Online, Caderno Ideias. Sábado, 16 de outubro de 1999.
} 
PROGRAMA DE PÓS-GRADUAÇÃO EM COMUNICAÇÃO DA UNIVERSIDADE FEDERAL DE SANTA MARIA

Assim, outra conclusão que se atreve chegar aqui é que se confirma a ideia, presente na narratologia estruturalista e em Joseph Campbell, de que as histórias/estórias, sejam elas orais, escritas ou audiovisuais, formam uma única narrativa que conta a si mesma e que tem por referência principal sua própria estrutura.

E que eu apenas transmito o que me disseram...

\section{REFERÊNCIAS}

BAITELLO JR., N. A serpente, a maçã e o holograma - esboços para uma teoria da mídia. São Paulo: Editora Paulus, 2010.

BARTHES, Roland; GREIMAS, A. J.; ECO, Umberto; e outros. Análise Estrutural da Narrativa. Petrópolis: Vozes, 2008.

BENJAMIM, Walter. v. I, A obra de arte na época de sua reprodutividade técnica. Obras Escolhidas (trad. S.P. Rouanet). São Paulo: Brasiliense, 1985.

. Sobre alguns temas em Baudelaire. Os Pensadores. São Paulo: Editora Abril, 1980. . Sobre o conceito de história. Obras escolhidas I. São Paulo: Brasiliense, 1985a. O narrador. Obras escolhidas I. São Paulo: Brasiliense, $1985 b$.

CAMPBELL, Joseph. O Herói de Mil Faces. São Paulo, Editora Cultrix/Pensamento, 1995. O Poder do Mito. Editora Palas Athena, São Paulo, 1990.

COSTA, Cláudio F. A Essência da Grande Arte. Revista Vivência, n.30. Natal, UFRN, 2006. p. 25-34.

ECO, Umberto. Leitor in Fábula. Editora Perspectiva, São Paulo, 1976.

ELIADE, Mircea. O sagrado e o profano. São Paulo: Martins Fontes, 1992.

FREUD, Sigmund. A interpretação dos Sonhos. In Obras Completas. Volume IV. São Paulo: Imago, 1990.

GENETT, Gerard. O Discurso da Narrativa. Lisboa: Vega, 1972.

GOMES, Marcelo Bolshaw. A história de Jesus Cristo como narrativa. Lisboa: Biblioteca Online de Ciências da Comunicação (BOCC), 2011. http://www.bocc.ubi.pt/pag/gomesmarcelo-a-historia-de-jesus-cristo-como-narrativa.pdf

Comunicação e Hermenêutica - apontamentos para uma teoria narrativa da mídia.

Revista Comunicação Midiática, v.7, n.2, p.26-46, maio/ago. 2012. 
GREIMAS, A. J. Semântica estrutural. São Paulo, Cultrix \& Edusp, 1976.

GREIMAS, A. J. e COURTÉS, J. Dicionário de semiótica. São Paulo: Cultrix, 1989.

JENKINS, Henry, Cultura da Convergência, trad. de Susana Alexandria, $1^{a}$ edição. São Paulo: Editora Aleph, 2008.

MARTINEZ, Mônica. Jornada do herói - a estrutura mítica na construção de histórias de vida em jornalismo. São Paulo: Annablume, 2008.

NIETZSCHE, F.W. Genealogia da moral: uma polêmica. Tradução, notas e posfácio de Paulo César de Souza. São Paulo: Cia das Letras, 2002.

PROPP, Vladimir. Morfologia do Conto Popular. Lisboa: Editora Vega, 1978.

RICOEUR, Paul. Tempo e Narrrativa - tomos I, II e III (1983; 1984; 1985); Campinas, Ed. Papyrus: 1994; 1995; 1997.

SIMPKINSON, Charles \& Anne. Histórias Sagradas: uma exaltação do poder de cura e transformação; tradução: Ione Maria de Souza Ferreira. Coleção Arco do Tempo. Rio de Janeiro: Rocco, 2002.

TAVARES, Braulio. O que é ficção científica. Coleção primeiros passos. 2a. Edição no. 169. São Paulo: Edit. Brasiliense, 1992.

VOGLER, Christopher. A Jornada do Escritor. Rio de Janeiro, Ampersand Editora, 1997.

\section{Referências Audiovisuais}

The Matrix. Direção: Andy Wachowski; Larry Wachowski; Produção: Joel Silver; Coprodução: Dan Cracchiolo; Produção executiva: Bruce Berman, Andrew Mason, Barrie M. Osborne, Erwin Stoff, Andy Wachowski, Larry Wachowski; Roteiro: Andy Wachowski, Larry Wachowski; Elenco: Keanu Reeves, Laurence Fishburne, Carrie-Anne Moss, Hugo Weaving. Produção Estados Unidos $1999 \bullet$ cor • 136 min.

The Matrix Reloaded. Direção: Andy Wachowski, Larry Wachowski; Produção: Joel Silver; Produção executiva: Bruce Berman, Grant Hill, Andrew Mason, Barrie M. Osborne, Erwin Stoff, Andy Wachowski, Larry Wachowski; Roteiro: Andy Wachowski, Larry Wachowski; Elenco: Keanu Reeves, Carrie-Anne Moss, Laurence Fishburne, Hugo Weaving. Produção Estados Unidos, Austrália 2003a • cor • 138 min.

The Matrix Revolutions. Direção: Andy Wachowski, Larry Wachowski; Produção: Joel Silver; Produção executiva: Bruce Berman, Grant Hill, Andrew Mason, Barrie M. Osborne, Erwin Stoff, Andy Wachowski, Larry Wachowski; Roteiro: Andy Wachowski, Larry Wachowski; Elenco: Keanu Reeves, Laurence Fishburne, Hugo Weaving, Carrie-Anne Moss. ProduçãoEstados Unidos, Austrália 2003b • cor • 129 min. 
Marcelo Bolshaw Gomes

Possui graduação em Comunicação Social - Jornalismo pela Faculdade de Comunicação e Turismo Hélio Alonso (1984), mestrado em Ciências Sociais pela Universidade Federal do Rio Grande do Norte (1998) e doutorado em Ciências Sociais pela Universidade Federal do Rio Grande do Norte (2006). Atualmente é professor associado da Universidade Federal do

Rio Grande do Norte. Leciona sociologia da comunicação para turmas de jornalismo, publicidade e rádio/TV e a disciplina de metodologia em estudos midiáticos no programa de pós-graduação em estudos da mídia (PPGEM/UFRN).

Esta obra está licenciada sob uma Licença Creative Commons. 